\title{
A note on inflation targeting and economic growth in Brazil
}

GILBERTO LIBÂNIO*

This paper analyzes the relation between monetary policy and economic performance in Brazil during the period 1999-2006. In particular, it discusses the growth effects of the inflation targeting regime through its effects on aggregate demand. It is argued that monetary policy under IT reacts in a procyclical and asymmetric way to fluctuations in economic activity (too "tight" during recessions, not so "loose" during expansions). Such pattern may generate a downward bias in aggregate demand, with negative real effects on output growth and employment. Our results suggest that monetary policy has been procyclical and asymmetrical in Brazil under inflation targeting. The main economic policy implication of this study is that central banks should consider more seriously the real effects of monetary policy on output and employment.

Keywords: Monetary policy; inflation targeting; aggregate demand.

JEL Classification: E52; E58.

\section{INTRODUCTION}

The Brazilian economy has experienced relatively low growth rates in the current decade. GDP has grown around 3\% per annum between 2000 and 2006, and such average is clearly lower than the average growth of middle income countries (around 5\% p.a.) and upper middle income countries (around 4\% p.a.) during the same period. On the other hand, the economic performance of the Brazilian economy in the 2000s is also worse than the long term growth averages experienced during most of the XX century, despite the current government's discourse pro-growth and the promise of a growth spectacle in Brazil.

This paper discusses one specific factor which may help to explain the poor

\footnotetext{
* Professor adjunto da Faculdade de Ciências Econômicas, Centro de Desenvolvimento e Planejamento Regional da Universidade Federal de Minas Gerais. E-mail: Gilberto@cedeplar.ufmg.br. Submetido: Julho 2007; Aprovado: Outubro 2008.
} 
economic performance of the Brazilian economy in this decade. That is, it is argued that the way monetary policy has been conducted under the inflation targeting (IT) regime in Brazil brings about an upward bias in interest rates, which harms aggregate demand through different channels and, as a consequence, negatively affects economic growth - at least in the short run. One of the main issues to be addressed in this study is the procyclical character of monetary policy under inflation targeting in developing countries, with liberalized capital accounts and flexible exchange rates. It is argued that not only monetary policy is procyclical under inflation targeting, but also that it is likely to react in an asymmetric way to fluctuations in economic activity and exchange rates (too "tight" during recessions, not so "loose" during expansions). Such pattern generates a downward bias in aggregate demand, with negative long-run real effects on output growth and employment.

Two qualifications to this argument are necessary. First, procyclical monetary policy in developing countries does not occur only under inflation targeting regimes. It is also a feature of countries with fixed exchange rates and open capital accounts, and in which monetary policy is mainly conditioned by international capital flows. Second, this paper does not argue that inflation targeting should not have been adopted by the Brazilian monetary authorities, or that the country would be better off by not adopting the regime. It just explores some important (although often neglected) features of the regime in a specific country where inflation targeting has actually been implemented.

The remainder of this paper is organized as follows. Next section will briefly review the features of the inflation targeting framework in Brazil, and will describe the main transmission mechanisms of monetary policy. Afterwards, the procyclical and asymmetrical nature of monetary policy will be analyzed, and the possible long-run effects on output and employment will be considered. Finally, a specification for testing whether monetary policy has been procyclical and asymmetrical in Brazil under inflation targeting will be outlined, and some results will be presented.

\section{INFLATION TARGETING IN BRAZIL}

A growing number of developing countries have adopted the inflation targeting (IT) framework, particularly since the late 1990s. This group includes Brazil, Chile, Colombia, Czech Republic, Hungary, Israel, Mexico, Peru, Philippines, Poland, South Africa, South Korea, Thailand, and (quite recently) Turkey. The specific details and the circumstances that led to the adoption of the framework vary from country to country. In some cases, the inflation targeting regime was implemented gradually, with the sequential introduction of the mechanisms that formally characterize the framework. In others, it was introduced rapidly, as a response to financial or 
currency crises that caused the abandonment of previous monetary arrangements and led to the search for new "nominal anchors" for monetary policy. ${ }^{1}$

The case of Brazil fits better in the second group. The inflation targeting regime was adopted in mid-1999, a few months after the abandonment of the quasi-fixed exchange rate regime that was the basis of Real Plan of stabilization from 1994 to 1998. It was argued at the time that the adoption of floating exchange rates required a new nominal anchor for economic policy, and that the target for inflation would be able to play such role. In addition, it was pointed out by the monetary authorities that low and stable inflation was the primary objective of monetary policy, and that the central bank's attention would be focused on the long-term consequences of short-term policies. Given the widespread belief of money neutrality in the long-run, this is equivalent to say that the central bank would focus on the inflationary effects of monetary policy, and put less emphasis on the its real effects on economic activity. ${ }^{2}$

An important aspect of monetary policy - and, for the purposes of this paper, of inflation targeting - is the mechanisms through which changes in the interest rate affect the variables targeted by the central bank. In general, such effects are discussed by using structural macroeconomic models that allow for a clear description of how the various macroeconomic variables relate to each other, as well as for simulations of the effects of shocks to exogenous variables. For the Brazilian case, models of this kind are presented in two working papers from the Central Bank research department: Bogdanski, Tombini and Werlang (2000, Working Paper n. 1, henceforth BTW) present a simple four-equation model, and Muinhos and Alves (2003, Working Paper n. 64 , hereafter MA) develop a medium-size structural model. The analysis and simulations from these models may be taken as representatives of the way the central bank analyzes the economy, and as useful guides to the decisions of the monetary policy committee in Brazil under IT. Accordingly, some aspects of these models will also be used in the arguments discussed here.

As it is well known, the primary instrument of monetary policy under IT is the short-term interest rate (Selic, in Brazil), which is set by the Central Bank following some kind of monetary policy rule. Usually, some variation of Taylor rule is adopted, in which the interest rate reacts (with variable weights) to output gap and to deviations of actual or expected inflation from the inflation target. In a small structural model, the transmission from interest rates to inflation occurs mainly via two channels. The first one is the output gap channel, in which increase in interest rates negatively affect aggregate demand (with a time lag), especially via investment and consumption durables. Such effect causes a widening of the output gap, and decreasing inflation (with a time lag) via the Phillips Curve. For the Brazilian econ-

\footnotetext{
${ }^{1}$ On inflation targeting in emerging market economies, see Blejer et al. (2000), Caballero and Krishnamurthy (2003), Mishkin (2004), and Truman (2003).

${ }^{2}$ Due to space constraints, this paper will not provide a more detailed description of the motivations and the implementation of the inflation targeting regime in Brazil. In this respect, see Bogdanski, Tombini and Werlang (2000).
} 
omy, BTW (2000, p. 14) state that "the monetary policy transmission through the aggregate demand channel takes between 6 to 9 months to fully operate".

The second transmission mechanism is the exchange rate channel, in which an increase in interest rates causes an appreciation of the domestic currency, via the uncovered interest parity condition. ${ }^{3}$ This, in turn, contemporaneously reduces inflation via a decrease in the price of tradable goods. It is worth noting that, in an open economy, the appreciation of the currency also impacts the economy via the aggregate demand channel, due to a reduction in net exports.

In sum, according to the described transmission mechanisms, the central bank should increase the short-term interest rate whenever expected inflation exceeds the target, and reduce interest rates in the opposite scenario. As I will argue in the next section, such pattern of behavior helps to explain the procyclical character of monetary policy under IT in developing countries.

\section{INFLATION TARGETING AND PROCYCLICAL MONETARY POLICY IN DEVELOPING COUNTRIES}

It is widely recognized that macroeconomic policies in developing countries tend to operate in a procyclical way, and are strongly influenced by international capital flows (Ffrench-Davis, 2003; Ocampo, 2003). The recent experience of emerging market economies and the financial and currency crises in the 1990s suggest that capital account cycles decisively affect domestic policies and are subject to high levels of volatility and contagion. Moreover, the rapid process of financial liberalization during the last decade seems to have increased the vulnerability of these economies to swings in international capital markets. ${ }^{4}$

Concerning monetary policy, it can be shown that a procyclical pattern may emerge in developing countries with liberalized capital accounts under different exchange rate arrangements. In case of fixed exchange rates, the explanation is straightforward, since monetary policy is passive to capital flows (according to basic open economy macroeconomic theory). Net inflows lead to expansionary monetary policy while net outflows lead to monetary contractions. The case of "fear of floating" (Calvo and Reinhard, 2002), in which countries that are considered to have a flexible exchange rate regime do not allow their currencies to fluctuate freely, can also explain procyclical monetary policies.

The case of flexible exchange rates is more interesting for the purposes of this

\footnotetext{
${ }^{3}$ According to the uncovered interest parity condition, expected changes in the nominal exchange rate depend (negatively) on the interest rates differential and (positively) on the country risk premium.

${ }^{4}$ Caballero and Krishnamurthy (2003) acknowledge the effects of "sudden stops" in capital flows in emerging economies. In order to minimize the procyclical character of monetary policy, they propose two alternatives, namely, a state-contingent inflation targeting regime and a target that overweighs non-tradable inflation.
} 
study, since it is more commonly associated to the inflation targeting framework and, in particular, it has been adopted by Brazil when the IT regime was implemented. In this paper, I will make a case that inflation targeting contributes to the procyclical character of monetary policy in emerging market economies with liberalized capital accounts and flexible exchange rates, and apply such reasoning to the case of Brazil. Most importantly, I want to argue that procyclical monetary policies are not only caused by large external shocks or crises, but they are a feature of the regime even under "normal" times and do not depend on the occurrence of significant capital inflows or outflows. ${ }^{5}$

So, the question to be addressed is: if monetary policy is procyclical under inflation targeting, what mechanisms can explain such behavior? First of all, the fact that country risk perception tends to increase when economic activity slows down. For instance, take the assumption that fiscal revenues depend on value added taxes or other forms of taxation that are sensitive to the level of GDP. In this case, when the economy is hit by a negative exogenous shock - leading to a slowdown in economic activity - fiscal revenues tend to decline. Muinhos and Alves (2003), in their medium-size structural model for the Brazilian economy, represent such relation as (equation 9 , page 14):

$$
T_{t}^{T}=\alpha_{0}+\alpha_{1} \cdot T_{t-1}^{T}+\sum_{i=1}^{3} \beta_{i} \cdot Y_{t-i}
$$

where $T^{T}$ stands for total tax, and $Y$ is GDP.

The estimated $\beta_{i}$ coefficients for the period 1996-2001 are $\beta_{1}=0.464, \beta_{2}=$ $-0.290, \beta_{3}=0.371$, confirming the hypothesis that tax revenues decline in periods of recession.

However, falling fiscal revenues in periods of slow growth are not necessarily accompanied by a decrease in government expenses in the same proportion or with the same speed (e.g., due to "rigidities" in certain types of expenses or to political constraints). Therefore, it is clear that fiscal surplus tend to be reduced (or fiscal deficit tends to be amplified) and this may lead to an increase in country risk premium, given the lower capacity of the country to repay external debt. In other words, there will be an inverse relation between fiscal results and country risk premium. As BTW (2000, p. 23) put it: "The risk premium will respond to the fiscal stance, with any perceived improvement in the consolidated public sector fiscal position reducing the premium accordingly".

In Muinhos and Alves's structural model, the relation between fiscal results and risk premium is given by (equation 31, page 29):

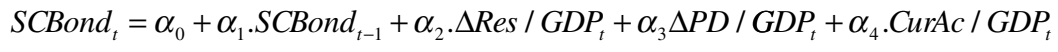

\footnotetext{
${ }^{5}$ But see also Calderon and Schmidt-Hebbel (2003), who argue that the ability to pursue countercyclical policies depends on the country-risk premium, i.e., countries with low risk-premium would be able to do it, while the ones with high risk-premium would not.
} 
where $S C B$ ond $=\mathrm{C}$-Bond spread over treasury; Res $/ G D P_{t}=$ foreign reserves $(\% \mathrm{GDP}) ; P D / G D P_{t}=$ public debt $(\% \mathrm{GDP}) ; \mathrm{CurAc} / G D P_{t}=12$ month accumulated current account balance (\%GDP).

According to the argument developed above, we could expect an increase in public debt to cause an increase in the risk premium. The estimated coefficient in the model for the period 01:1996 to 12:2001 is positive (0.1360) and significant at $10 \%$, in accordance with our expectations.

The next step to be discussed is the relation between country risk and nominal exchange rates. As the recent experience of emerging markets with flexible exchange rates has shown, an increase in country risk premium may lead to a change in the portfolio of private investors and, consequently, to the depreciation of the domestic currency. Again, following MA (2003), this relation could be described as (equation $30 \mathrm{~b}$, page 27 ):

$$
\Delta \varepsilon_{t}=A_{1} \cdot \Delta \varepsilon_{t-1}+A_{2} \cdot \Delta\left(r_{t-1}-r_{t-1}^{f}\right)+A_{3} \cdot \Delta \text { SCBond }_{t}+A_{4} \mu_{t-1}
$$

where (all variables are specified in logs): $\varepsilon_{\tau}=$ real exchange rate; $r_{t}=$ short run real interest rate; $r^{f}=$ foreign short run interest rate; $\mu_{t}=$ random error term.

For the period 1999-2002, the estimated coefficient $A_{3}=16.384$, suggesting a strong reaction of the real exchange rate to changes in the risk premium. Depreciation of the domestic currency, in turn, impacts the expectations of inflation in the next periods, due to increase in the price of tradable goods (pass-through). Under inflation targeting, the central bank would react to the rise in actual or expected inflation by tightening the monetary policy (i.e., increasing interest rates), according to a standard Taylor rule such as (MA, 2003, equation 35, page 32):

$$
i_{t}=\gamma_{1} \cdot i_{t-1}+\left(1-\gamma_{1}\right) \cdot\left\{\gamma_{2} \cdot\left[\sum_{i=1}^{4}\left(\pi_{t-i}-\pi_{t-1}^{T \text { arget }}\right)\right]+\gamma_{3} \cdot h_{t-1}+i_{t}^{E q}\right\}
$$

where $i$ refers to the interest rate, $\pi$ is inflation and $b$ is the output gap. In the baseline scenario adopted by MA (2003) for estimations, the $\gamma_{2}$ coefficient (which gives the sensibility of the interest rate to the "inflation gap") is arbitrarily set to 1.3.

The increase in the interest rate in reaction to the rise of inflation would amplify the decline in economic activity by reducing private spending and also affecting public spending (since higher interest rates imply higher interest payments on existing public debt and the necessity to generate a higher primary surplus). ${ }^{6}$ To

\footnotetext{
${ }^{6}$ There is a limiting case in which the reaction of the central bank can lead the system to divergent behavior. This happens when the effect of the rise in interest rates on government debt leads to the perception that the debt trajectory is unsustainable and that the government will not be able to honor its payments. In this case, we would observe capital flight, further currency depreciation, leading to further increases in interest rates and so on. This is the classic example of "fiscal dominance", and will not be explored here (see Blanchard, 2004, for an analysis of fiscal dominance in the Brazilian economy).
} 
summarize: in this example, the initial recession was followed by a restrictive monetary policy which pushed the economy further down - a procyclical monetary policy.

In principle, the same mechanism would operate in periods of economic expansion: higher fiscal revenues leading to decrease in country risk premium and consequent appreciation of the domestic currency. Appreciation, in turn, would lead to a decrease in expected inflation, allowing for a fall in interest rates.

I would argue, however, that monetary policy does not operate in a symmetrical way under these circumstances. In other words, the central bank under inflation targeting would in general react more strongly to exchange rate depreciations than to exchange rate appreciations. The reason for this behavior is the weight of inflation stabilization in the central bank's reaction function: when the domestic currency is depreciating, prompt reaction is needed if the inflationary effects of depreciation are to be offset; when the currency is appreciating, the deflationary effects are not counterbalanced with the same intensity, since they may help the central bank to achieve the target for inflation, especially in periods of disinflation or after the economy has suffered negative supply shocks.

In sum, the argument advanced here is that this asymmetric reaction is likely to occur in developing countries under inflation targeting and flexible exchange rates, and may generate an upward bias to interest rates. In addition, this may cause a tendency for the exchange rate to appreciate - as argued by Galindo and Ros (2006), and confirmed for the Brazilian case by the negative and significant coefficient $A_{2}$ on equation (3) above - which may bring structural competitiveness pressures to the domestic industry, as we see nowadays in Brazil. This situation characterizes what Bresser-Pereira and Gomes (2006) call the "high interest rate / low exchange rate trap". The final result is a downward bias to aggregate demand - investment, consumption, net exports - which brings about negative effects on output and employment.

It is interesting to note that inflation targeting per se-i.e., the formal mechanism of announcing a target for inflation to guide expectations, the search for increasing transparency by the publication of inflation reports, and so on - is not the main problem. In principle, such framework is also consistent with directing monetary policy toward real objectives like output and employment. As many supporters (e.g., Bernanke et al., 1999) have emphasized, inflation targeting do not imply a rigid monetary policy rule, and provides enough flexibility for the central bank to respond in various directions to changes in the environment. However, the problem is that in practice central banks under inflation targeting tend to place an increased focus on inflation and tend to be less concerned with output fluctuations. As Benjamin Friedman (2002, p. 7) puts it:

Notwithstanding the compatibility in principle of inflation targeting as a conceptual framework for implementing a monetary policy in which real outcomes matter as well as inflation, an observer who has paid at- 
tention to the last quarter century of debate about monetary policy is entitled to suspect that a powerful motivation for adopting this framework, at least in some quarters, is the hope that if explicit discussion of central bank's policy is carried out entirely in terms of an optimal inflation trajectory, concerns for real outcomes may somehow atrophy or even disappear from consideration altogether.

In fact, most of the discussion about monetary policy under inflation targeting is devoid of any explicit reference to real outcomes, except for the recognition that increase in interest rates may cause a decline in aggregate demand in the short run, and this is one of the channels through which monetary policy may affect inflation. Mishkin (2002) provides a theoretical rationale for central bank behavior under inflation targeting and argues that "too much focus" on output fluctuations in discussion of monetary policy is likely to produce worse outcomes for output and inflation. This argument is based on two elements: (i) monetary policy that responds actively to output fluctuations tend to be suboptimal, since it is hard to measure output gap, and its theoretical concept is controversial; (ii) "language which stresses output goals can make a central bank's communication strategy less effective and can thereby weaken monetary policy credibility" (Mishkin, 2002, p. 1).

There is also empirical evidence that shows that central banks have become more focused on inflation after adoption of inflation targeting. Cecchetti and Ehrmann (1999) compare central bank behavior in 23 developed and developing countries, and find that inflation targeters exhibit increasing aversion to inflation variability and decreasing aversion to output variability. Moreover, they show that inflation targeting countries were able to reduce inflation volatility at the expense of an increase in output variability. Minella et al. (2003) estimate a reaction function for the central bank of Brazil, and show that the monetary authority has strongly reacted to inflation expectations. At the same time, it is interesting to note that the coefficient on output gap is not statistically significant in most of the specifications.

In summary, it is clear that inflation targeting regimes imply a strong emphasis on inflation stabilization, with low concerns for real effects on output and employment. As discussed before, such central bank behavior may generate a procyclical and asymmetrical pattern in monetary policy and deepen economic contractions, especially in emerging market economies with liberalized capital accounts. In the next section, I will develop a specification for testing the hypotheses of procyclical and asymmetric monetary policy, and present some results for the Brazilian case (1999-2006). 


\section{PROCYCLICAL AND ASYMMETRIC MONETARY POLICY IN BRAZIL: AN EMPIRICAL ESTIMATION}

To the best of my knowledge, only a few studies provide empirical estimates on the procyclical character of monetary policy in Latin America. Calderon and Schmidt-Hebbel (2003) analyze a panel of eleven emerging market economies over the period 1996-2002 (annual data). Their findings suggest that the cyclical character of monetary policy depend on country risk premium: policy is procyclical when country risk is high and countercyclical when it is low.

Costa e Silva (2004) provides a test for procyclical monetary and fiscal policy in Argentina, Brazil, Chile and Mexico using annual data for the period 1970-2000. The focus of his study is the influence of capital flows on macroeconomic policy and the feedback effect of policy on capital flows, and no particular attention is given to inflation targeting. Costa e Silva (2004) finds that monetary policy has been procyclical in three of the four countries analyzed, and that it has been correlated to the fluctuations of international capital flows.

In this paper, I analyze the procyclical and asymmetrical character of monetary policy under inflation targeting by estimating the relation between economic activity and interest rates. In other words, I want to evaluate how monetary policy has responded to fluctuations in output, especially in the downturn of the cycle. Since it is also expected that interest rates affect economic activity, this study will use a Vector Autoregression (VAR) model, in order to allow for these feedback effects. In structural form, the model can be written as:

$$
\begin{gathered}
r_{t}=A_{1}+\sum_{j=0}^{n} \alpha_{1 j} \Delta y_{t-j}+\sum_{j=1}^{n} \alpha_{2 j} . r_{t-j}+B_{1} X_{t}+\varepsilon_{1 t} \\
\Delta y_{t}=A_{2}+\sum_{j=1}^{n} \beta_{1 j} \Delta y_{t-j}+\sum_{j=1}^{n} \beta_{2 j} . r_{t-j}+\beta_{2} X_{t}+\varepsilon_{2 t}
\end{gathered}
$$

where $r$ represents short term real interest rates (deflated by consumer price index, IPCA), $y$ corresponds to the level of output, and $X$ are the control variables, namely, changes in oil prices (to capture supply shocks) and in US interest rates (to capture changes in international liquidity). ${ }^{7}$ In this case, a negative sign for the parameters $\alpha_{1 j}$ would suggest that monetary policy follows a procyclical pattern, that is, the central bank tightens monetary policy in periods of declining economic activity.

On the other hand, by separating periods of expansion and contraction, I intend to assess the asymmetrical character of monetary policy, and verify whether the

\footnotetext{
${ }^{7}$ I have estimated the model with both control variables, with only one of them, and with none. All results are provided in Tables 1.1 and 1.2, but only the impulse response functions of the complete specification are presented here. All the estimations were made using E-Views 5.0.
} 
monetary authorities in Brazil have responded in different ways in the various phases of the business cycle. This task will be accomplished by creating two dummy variables: (i) GOOD, which takes the value 1 in periods when GDP is above a linear trend and 0 otherwise, and (ii) $\mathrm{BAD}$, which is symmetrical to GOOD. By multiplying the dummy variables to the rates of growth in the three economies, I create two separate series describing "good times" and "bad times", and then proceed to estimate whether or not monetary policy has responded differently to booms and recessions. In this case, the resulting equations are:

$$
\begin{aligned}
& r_{t}=A_{1}+\sum_{j=0}^{n} \alpha_{1 j} \Delta y G O O D_{t-j}+\sum_{j=0}^{n} \alpha_{2 j} . \Delta y B A D_{t-j}+\sum_{j=1}^{n} \alpha_{3 j} \cdot r_{t-j}+\beta_{1} X_{t}+\varepsilon_{1 t} \\
& \Delta y G O O D_{t}=A_{2}+\sum_{j=0}^{n} \beta_{1 j} \Delta y G O O D_{t-j}+\sum_{j=0}^{n} \beta_{2 j} . \Delta y B A D_{t-j}+\sum_{j=1}^{n} \beta_{3 j} \cdot r_{t-j}+\beta_{2} X_{t^{+}} \varepsilon_{2 t} \\
& \triangle y B A D_{1}=A_{3}+\sum_{j=0}^{n} \delta_{1 j} \Delta y G O O D_{t-j}+\sum_{j=0}^{n} \delta_{2 j} \cdot \Delta y B A D_{t-j}+\sum_{j=1}^{n} \delta_{3 j} . r_{t-j}+\beta_{3} X_{t^{+}} \varepsilon_{3 t}
\end{aligned}
$$

I have estimated the outlined model for the period when inflation targeting has been fully implemented in Brazil (1999-2006), using monthly data. The seasonally adjusted Industrial Production Index, from IBGE, was used as proxy for GDP. The real interest rate was calculated using the annualized Selic rate (montlhy averages), from the Central Bank of Brazil, deflated by the consumer price index IPCA, also from IBGE.

Before proceeding to the estimation, I checked for stationarity of the series using the Augmented Dickey-Fuller (ADF) test, and the null of unit roots was rejected at $5 \%$ for all series. In addition, the choice of lags for the endogenous variables in the VAR was based on the Schwarz Information Criterion, which tends to be parsimonious in terms of lag lengths. SIC was also used for the choice of lags of control variables.

For the most part, the estimation results provide support for the arguments presented here. In the case of Brazil, the negative coefficients on GDP growth in equation (5) suggest that monetary policy has been procyclical under inflation targeting (see Table 1.1 and Graph 1.1 in Appendix). The results regarding the asymmetric behavior of monetary policy are also in line with what was expected. Policy has been procyclical in good and bad times, but the estimated coefficients are higher and are only significant for the latter, suggesting that the central bank reaction tends to be stronger in bad times: "too tight during contractions, not so loose during expansions" (Table 1.2 and Graph 1.2, Appendix).

Overall, the results presented here suggest that the inflation targeting regime in Brazil may bring about an upward bias to interest rates, with negative consequences to aggregate demand, given the asymmetrical reaction of the central bank to the business cycle.

As it is well known, the real effects to aggregate demand are usually not con- 
sidered to affect growth rates in the long run, when monetary policy is regarded as neutral by assumption. In MA (2003), for instance, long-run neutrality is assumed by imposing restrictions on the coefficients as to guarantee a vertical Phillips Curve in the long run. However, it is acknowledged in the model that higher interest rates will affect investment and "a lower level of investment will cause a decrease in the growth rate of the capital stock, affecting potential output growth" (MA, 2003, p. 7). This result also appears in the simulations of the model, when alternative Taylor rules with different weight coefficients are compared. In this case, the more aggressive monetary policy is - higher weight in the "inflation gap" - the lower is GDP growth (for the first three years or so).

Therefore, although the negative effects on GDP suggested by the analysis presented here refer mainly to short run effects, there seem to be good theoretical and empirical reasons to argue that such effects may last for a long time ${ }^{8}$. In this case, there seem to be a trade-off between inflation and unemployment that go beyond the short run, which makes restrictive monetary policies more problematic than what the conventional view on money neutrality would acknowledge.

\section{CONCLUSIONS}

This paper has discussed the real effects of monetary policy on GDP in Brazil, since the implementation of the inflation targeting regime. The main question under consideration here is whether or not monetary policy reacts in a procyclical and asymmetrical way to economic activity. The paper suggests that such behavior is likely to produce an upward bias in interest rates and a consequent downward bias in aggregate demand, and bring about negative effects on growth rates, at least in the short run.

An empirical model has been estimated to evaluate monetary policy in Brazil during the period 1999-2006. The results suggest that monetary policy has been procyclical and asymmetric in Brazil, so that it can be described by the expression "too 'tight' during contractions, not so 'loose' during expansions". In this case, it can be argued that monetary policy under inflation targeting has been detrimental to aggregate demand and growth.

The results described here partly confirm the findings of Costa e Silva (2004) who used annual data during the period 1970-2000 to find a procyclical monetary policy in Brazil. On the other hand, they do not conform to the results of Calderon and Schmidt-Hebbel (2003), who found a correlation between country risk premium and the response of monetary policy to GDP growth.

I conclude this paper by making a few comments about further avenues for

\footnotetext{
${ }^{8}$ This argument is also put forward - from different viewpoints - by Barbosa-Filho (2006), Bresser-Pereira and Gomes (2006), Carvalho (2005), Galindo and Ros (2006).
} 
empirical research that would help to clarify some of the issues not resolved here. First, the sample can be expanded to include other developing countries in Latin America and elsewhere which adopted the inflation targeting framework. Second, more research on the relation between interest rates, exchange rates, and GDP growth is welcome. The work of Galindo and Ros (2006) presents a promising avenue in this direction by estimating the asymmetric response of monetary policy to exchange rate movements in Mexico. The authors show that the inflation targeting framework has contributed to the appreciation of the real exchange rate, and this has had contractionary effects on output in the long run. ${ }^{9} \mathrm{~A}$ similar analysis could be applied to Brazil, since a quick look at the data suggests that the exchange rate has appreciated during the period under analysis, despite the peaks observed due to the uncertainty regarding the presidential election in 2002. ${ }^{10}$

Another concluding comment relates to the theme of aggregate demand and growth. It seems that the empirical analysis made in this paper does not provide a response to whether long-run output growth has been affected by monetary policy under inflation targeting. The idea that aggregate demand - and monetary policy, in particular - can influence growth in the long run has been extensively discussed in economics in recent years, and several channels through which demand affects growth have been identified ${ }^{11}$. This issue is not analyzed here, but our results suggest that long-run growth may have been affected in Brazil, if one accepts the assumption that growth is demand-led. Even if this is not the case, the very existence of imperfections and rigidities in the economy may make the adjustment process long enough for the effects on the real side of the economy to be relevant. Thus, one of the main contributions of this study is to point out to potential negative real effects of inflation targeting that are usually neglected in the IT literature, simply because of the assumption that aggregate demand fluctuations are irrelevant to long-term outcomes.

Finally, if it is true that monetary policy is procyclical and asymmetric under inflation targeting, and if it is accepted that demand changes can have long-lasting effects, the main economic policy implication of this study is that central banks should consider more seriously the real effects of monetary policy. In particular, the analysis would imply that the trade-off central banks face is not only between inflation and short-run output losses, but between inflation and long-lasting growth effects.

\footnotetext{
${ }^{9}$ In recent years, a growing literature has pointed out to the negative relationship between exchange rate appreciations and economic growth. See, for example, Aguirre and Calderón (2005), Rodrik (2007), Gala (2008).

${ }^{10}$ Between July 1999 and December 2006, the real exchange rate has declined between $20 \%$ and $50 \%$, depending on the inflation index used in the calculations (source: IPEADATA website).

${ }^{11}$ See Arestis and Sawyer (2002), Carvalho (2005), Dutt and Ros (2003), Lavoie (2004).
} 


\section{REFERENCES}

AGUIRRE, A. and C. CALDERÓN (2005) "Real exchange rate misalignments and economic performance". Documentos de Trabajo n. 315, Banco Central de Chile.

ARESTIS, Philip and Malcolm SAWYER (2002) "Can monetary policy affect the real economy?". The Levy Economics Institute Working Paper 355, October.

BALL, Laurence and Dean CROUSHORE (2003) "Expectations and the effects of monetary policy". Journal of Money, Credit and Banking, 35 (4): 473-84.

BALL, Laurence and Niamh SHERIDAN (2003) "Does inflation targeting matter?". IMF Working Paper 03/129, June.

BARBOSA FILHO, Nelson (2006) "Exchange rates, growth and inflation". Paper presented at the Annual Conference on Development and Change, Campos do Jordão, Brazil, November 2006.

BARBOSA FILHO, Nelson (2006b) "Inflation targeting in Brazil: Is there an alternative?" Political Economy Research Institute, Alternatives to Inflation Targeting, n. 6, September.

BERNANKE, Ben, Thomas LAUBACH, Frederic MISHKIN and Adam POSEN (1999) Inflation Targeting: Lessons from the International Experience. Princeton, NJ: Princeton University Press.

BLANCHARD, Olivier (2004) "Fiscal dominance and inflation targeting: lessons from Brazil”. NBER Working Paper 10389, March.

BLEJER, Mario, Alain IZE, Alfredo LEONE and Sergio WERLANG (eds) (2000) Inflation Targeting in Practice: Strategic and Operational Issues and Application to Emerging Market Economies, Washington, DC: International Monetary Fund.

BOGDANSKY, Joel, Alexandre TOMBINI and Sérgio WERLANG (2000) "Implementing inflation targeting in Brazil”. Banco Central do Brasil Working Paper, n. 1, July.

BRESSER-PEREIRA, L.C. and C. GOMES (2006), "Inflation targeting in Brazil: A Keynesian approach". $9^{\text {th }}$ International Post-Keynesian Conference. Kansas City (EUA), 2006.

CABALLERO, Ricardo and Arvind KRISHNAMURTHY (2003) "Inflation targeting and sudden stops”. NBER Working Paper 9599, April.

CALDERON, Cesar and Klaus SCHMIDT-HEBBEL (2003) "Macroeconomic policies and performance in Latin America". Journal of International Money and Finance, 22(7): 895-923.

CALVO, Guillermo A. and Carmen M. REINHART (2002) "Fear of floating". Quarterly Journal of Economics, 117 (2), May: 379-408.

CARVALHO, Fernando Cardim (2005) "Uma contribuição ao debate em torno da eficácia da política monetária e algumas implicações para o caso do Brasil”. Revista de Economia Politica, vol. 25, n. 4, out-dez: 323-336.

CECCHETTI, Stephen and Michael EHRMANN (1999) "Does inflation targeting increase output volatility? An international comparison of policymakers' preferences and outcomes”. NBER Working Paper 7426, December.

COSTA E SILVA, Jose Ricardo (2004) Essays on Finance and Business Cycles. unpublished Ph.D. Dissertation, Washington University in St. Louis.

DUTT, Amitava and Jaime ROS (2003) "Contractionary effects of stabilization and long run growth". Initiative for Policy Dialogue Working Paper, May.

FFRENCH-DAVIS, Ricardo (2003) "Financial crises and national policy issues: an overview". In: Ffrench-Davis, Ricardo and Stephany Griffith-Jones (eds) (2003) From Capital Surges to Drought: Seeking Stability from Emerging Economies. Basingstoke: Palgrave Macmillan.

FRAGA, Arminio, Ilan GOLDFAJN and Andre MINELLA (2003) "Inflation targeting in emerging market economies". NBER Working Paper 10019, October.

FRENKEL, Roberto (2006) "Alternatives to inflation targeting in Latin America: macroeconomic policies focused on employment”. Journal of Post Keynesian Economics, 28(4): 573:591.

FRIEDMAN, Benjamin (2002) "The use and meaning of words in central banking: inflation targeting, credibility, and transparency". NBER Working Paper 8972, June.

GALA, Paulo (2008) "Real exchange rate levels and economic development: theoretical analysis and econometric evidence”. Cambridge Journal of Economics, Jan-Mar. 
GALINDO, Luis M. and Jaime ROS (2006) “Alternatives to inflation targeting in Mexico”. Political Economy Research Institute, Alternatives to Inflation Targeting, n. 7, September.

LAVOIE, Marc (2004) "The new consensus on monetary policy seen from a post-Keynesian perspective". In: Lavoie, Marc and Mario Seccareccia (eds) (2004) Central Banking in the Modern World: Alternative Perspectives. Northampton, MA: Edward Elgar.

MINELLA, Andre, Paulo Springer de FREITAS, Ilan GOLDFAJN and Marcelo Kfoury MUINHOS (2003) "Inflation targeting in Brazil: Constructing credibility under exchange rate volatility". Journal of International Money and Finance, 22 (7), December: 1015-1040.

MISHKIN, Frederic (2002) "The role of output stabilization in the conduct of monetary policy". NBER Working Paper 9291, October.

MISHKIN, Frederic (2004) "Can inflation targeting work in emerging market countries?". NBER Working Paper 10646, July.

MUINHOS, Marcelo and Sérgio Afonso ALVES (2003) "Medium-size macroeconomic model for the Brazilian economy". Banco Central do Brasil Working Paper, n. 64, February.

NEUMANN, Manfred and Jurgen VON HAGEN (2002) "Does inflation targeting matter?". The Federal Reserve Bank of St. Louis Review, 84 (4), Jul-Aug: 127-146.

OCAMPO, Jose Antonio (2003) "Developing countries' anti-cyclical policies in a globalized world". In: Dutt, Amitava and Jaime Ros (eds) (2003) Development Economics and Structuralist Macroeconomics. Northampton, MA: Edward Elgar.

RODRIK, Dani (2007) "The Real exchange rate and economic growth: theory and evidence". John F. Kennedy School of Government, Harvard University, Draft, August.

SCHMIDT-HEBBEL, Klaus and Alejandro WERNER (2002) "Inflation targeting in Brazil, Chile and Mexico: Performance, credibility and the exchange rate". Economia, 2(2): 31-89.

TAYLOR, John (2000) "Teaching modern macroeconomics at the principles level". American Economic Review, 90 (2), May: 90-94.

TRUMAN, Edwin (2003) Inflation Targeting in the World Economy. Washington, DC: IIE.

Table 1.1: Testing for procyclical monetary policy (BRAZIL 1999-2006) VAR regression output

\begin{tabular}{lccc}
\hline & RIR & RIR & RIR \\
\hline RIR(-1) & 1.0005 & 1.0096 & 1.3338 \\
RIR(-2) & $(17.7040)$ & $(17.7646)$ & $(23.7751)$ \\
& -0.2590 & -0.2687 & -0.5077 \\
DGDP(-1) & $(-5.3606)$ & $(-5.5427)$ & $(-9.6203)$ \\
& $-0.1264 \mathrm{P}^{*}$ & $-0.1140 \mathrm{P}^{*}$ & $-0.1237 \mathrm{P}$ \\
DGDP(-2) & $(-2.7985)$ & $(-2.5323)$ & $(-2.0250)$ \\
& $-0.0200 \mathrm{P}^{*}$ & $-0.0126 \mathrm{P}$ & $0.1151 \mathrm{C}$ \\
C & $(-2.4003)$ & $(-0.2722)$ & $(1.9352)$ \\
& 2.7627 & 2.7549 & 1.8493 \\
D_OIL(-1) & $(13.7912)$ & $(13.6138)$ & $(8.1971)$ \\
& -0.0025 & 0.0013 & - \\
D_OIL(-2) & $(-0.2346)$ & $(0.1187)$ & - \\
& -0.0099 & -0.0059 & - \\
DUS_INTEREST(-1) & $(-0.9299)$ & $(-0.5665)$ & 0.9613 \\
\hline Adj. R-squared & 0.6130 & & - \\
\hline
\end{tabular}


Table 1.2: Testing for asymmetrical monetary policy (BRAZIL 1999-2006) VAR regression output

\begin{tabular}{lccc}
\hline & RIR & RIR & RIR \\
\hline RIR(-1) & 0.7154 & 0.7128 & 0.8934 \\
& $(38.3534)$ & $(37.7295)$ & $(28.4395)$ \\
DGDP_GOOD(-1) & $-0.0872 \mathrm{P}$ & $-0.0747 \mathrm{P}$ & $-0.0732 \mathrm{P}$ \\
& $(-1.2156)$ & $(-1.0301)$ & $(-0.4568)$ \\
DGDP_BAD(-1) & $-0.2126 \mathrm{P}^{*}$ & $-0.1956 \mathrm{P}^{*}$ & $-0.1053 \mathrm{P}$ \\
& $(-2.9123)$ & $(-2.6582)$ & $(-0.6868)$ \\
C & 2.9911 & 3.0028 & 1.0877 \\
& $(13.6583)$ & $(13.5077)$ & - \\
D_OIL(-1) & 0.0050 & 0.0106 & - \\
& $(0.4084)$ & $(0.8712)$ & - \\
D_OIL(-2) & -0.0226 & -0.0180 & \\
DUS_INTEREST(-1) & $(-1.8837)$ & $(-1.5118)$ & 0.8963 \\
& 0.8111 & - & \\
Adj. R-squared & $(1.9277)$ & 0.9469 & \\
\hline
\end{tabular}

Notes: P stands for procyclical; C for countercyclical; * indicates significance at $10 \%$ or less; t-statistics in parentheses.

\section{IMPULSE RESPONSE FUNCTIONS}

Graph 1.1: Testing for procyclical monetary policy:

BRAZIL 1999-2006 (model 1)

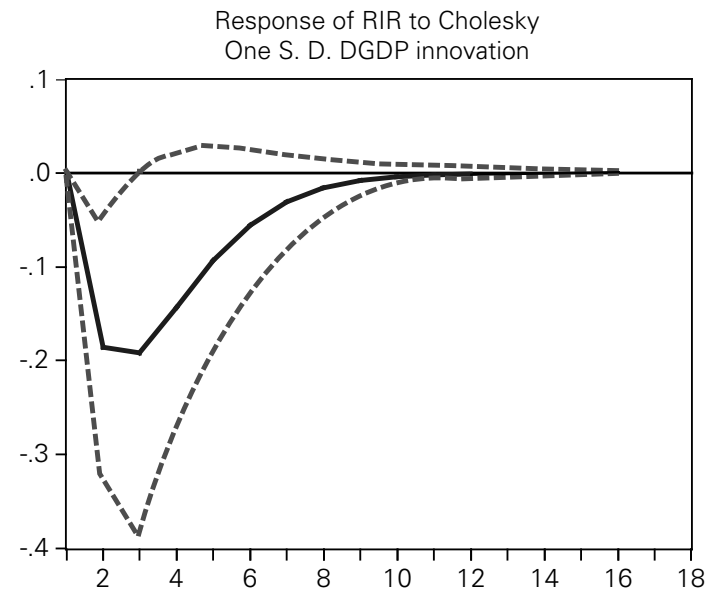


Graph 1.2: Testing for asymmetrical monetary policy: BRAZIL 1999-2006 (model 1)

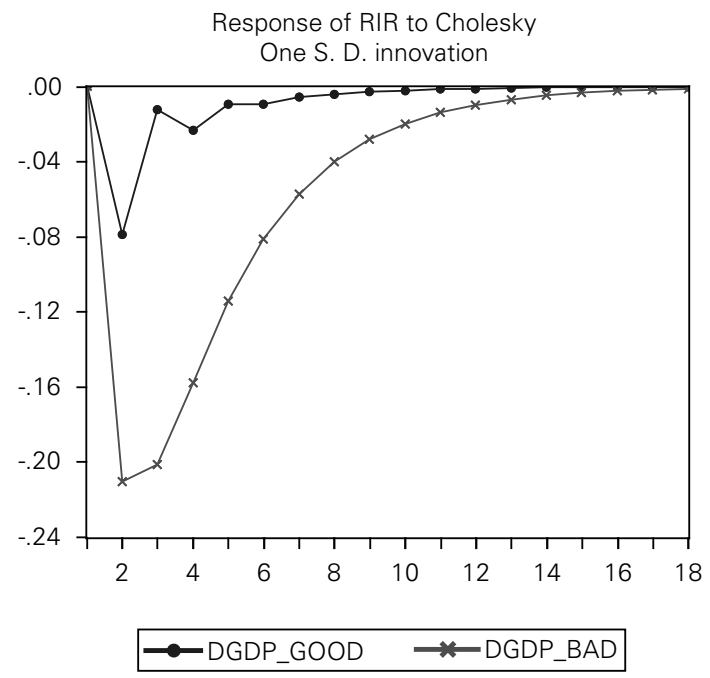

